\title{
Rosai Dorfman Disease
}

\author{
Kalpana Giri ${ }^{1}$, Ashok Baral ${ }^{2}$, Niva Tiwari $^{1}$, and Krishna Sharma ${ }^{1}$ \\ ${ }^{1}$ BP Koirala Memorial Cancer Hospital \\ ${ }^{2}$ National Medical College
}

June 29, 2021

\begin{abstract}
Rosai-Dorfman disease (RDD) is referred to as Sinus Histiocytosis Massive Lymphadenopathy (SHML) of unknown origin. We are reporting a rare case of Rosai Dorfman disease, a case of 6 years old male with a history of multiple painless bilateral submandibular and cervical lymphadenopathy.
\end{abstract}

\section{Hosted file}

Manuscript file.pdf available at https://authorea.com/users/422574/articles/528289-rosaidorfman-disease

\section{Hosted file}

Figure file.pdf available at https://authorea.com/users/422574/articles/528289-rosai-dorfmandisease 